\title{
Romantic Pedagogy in the Age of Revolutions: The Strange Career of Emile in America
}

\author{
Michael Zuckerman \\ University of Pennsylvania, Philadelphia, USA
}

\begin{abstract}
The puzzle is palpable. Jean-Jacques Rousseau was the most brilliant of all developmental psychologists and his Emile the most profound book ever written on education. In the age of revolutions, Rousseau was one of the two most widely read philosophes in America and Emile the most popular of all his writings. More even than all that, Rousseau's ideas about education were far more in tune with the rhetoric of revolutionary America than those of his only real rival in pedagogy, John Locke. Yet Rousseau's influence on education in the new nation was negligible. How are we to explain that? This paper suggests an answer to that question.
\end{abstract}

Keywords: Rousseau, Emile, Enlightenment, public education, Horace Mann, myth, individualism

\section{Introduction}

There is Rousseau, the most brilliant of all developmental psychologists, and his treatise Emile, the most brilliant book ever written on education. There is the Age of Reason and the new American nation it informed. And there is the system of public education that became a hallmark of the young republic and, for the next century, the marvel of the western world.

It is easy, even irresistible, to imagine that there are - must be - filaments of influence that tie Rousseau and the Enlightenment to the new schools of the United States. He was, with Voltaire, the most popular French writer in America, and of all his writings Emile was the most widely read (Spurlin, 1969, pp. 23-6, 71-2).

\section{Failure to Follow Rousseau}

But I see no consequential connection between Rousseau and American education in the formative era of the common school, and I don't see anyone else who sees one either. None of the leading authorities mention Emile in more than a subordinate clause or a fragment of a solitary sentence. Some mention him not at all.

This indifference to Rousseau is as intriguing as it is odd, because the standard histories of education and the family treat Locke and Rousseau as the transformative theorists of modern childhood. Why, in the nation where modern notions of childhood were most advanced, did no one need the ideas of the great philosophers? Why did the educational innovations that should have owed so much to them owe nearly nothing? Why does history turn out to be mostly a record of what might have happened but didn't? Or what happened in the wrong way, for the wrong reasons?

In all the world, Americans should have been most receptive to Rousseau's ideas and, indeed, most in need of them. In almost everything that mattered, Rousseau and the New World republicans espoused the same

Michael Zuckerman, Ph.D., Professor Emeritus of History, University of Pennsylvania. 
values and shared the same dilemmas.

He was as optimistic about man's natural goodness as they professed to be (and as John Locke was not). He was as devoted to liberty as they said they were (and as Locke, with his insistence on crushing the young child's will and instilling obedience, was not). He conceived of learning as the same self-motivated exploration that they prided themselves on pursuing (and that Locke, with his insistence on stern discipline and the denial of desire, did not). He had the same disdain for authority that they did (and that Locke, who urged the early imposition of parental power to crush childish impulses to willfulness and dominion, did not).

Just as Rousseau should have suited the Americans' notorious animus against authority, so he should have flattered their famous antagonism to intellect. He disdained even to allow his fictive pupil to learn to read before he reached adolescence. To the age of twelve, Emile's education was entirely by experience. He did not go to school, know of books, cultivate reason, or endure moral indoctrination. He spent most of his days outdoors, and he learned only what he found useful or pleasing.

Rousseau's raging diatribes against metropolitan sophistication anticipated the American Founders' denunciations of European learning. Just as he scorned the refinements of Paris, so those who thought about the character of the new country sought to keep young American minds from anything that could perpetuate monarchical manners or aristocratic affectations. Emile was a savage indictment of all that passed for sophisticated civility in the Old World. It should have provided Americans just the justification they sought to see themselves as virtuous youth turning away from the vicious and impotent senility of Europe.

And it should have done more, for it pointed to possibilities of organizing society on a different footing.

If America was to be something new under the sun, the new nation had to do more than simply set itself apart from the old nations by disparaging their accomplishments. It had actually to do something positive, to solve its own problems. It had to devise ways of passing on to its youth the fervor of the Revolution and the principles of the republic.

That was why education was such an urgent issue in the minds of the Founding Fathers. Without exception, Washington, Jefferson, and the rest of them stressed the imperative of transmitting their own precarious achievement to succeeding generations and of training young people for responsible self-rule. They all knew their history and their political theory. They all considered republics the least stable of all forms of rule. They all agreed that popular government required "an extraordinary degree of public-spiritedness and self-restraint" in the governed and that such virtues could only come of "intense moral education". And they all worried that such education was "a rare and fragile” thing (Pangle, 1993, p. 1).

Those convictions and concerns should have brought them all the more urgently to Rousseau, whose work was a lifelong exploration of the possibilities of a better life beyond the baleful influence of the court, the church, and the fashions of Paris. The point of the education he envisioned was not to make Emile a good student, a fine gentleman, a great scholar, or a courtier. It was to enable a young boy to become a happy and autonomous adult concerned for the common good. It was, as he said again and again, to allow Emile to grow up a man and a citizen.

In all the world, the United States was the nation with the most to learn from Rousseau's ideas. But American educators simply did not turn to Rousseau. Most of them never noticed him at all, and the few who paid him any heed denounced him more often than they defended him.

I do not profess to understand any of this. I can only count my perplexity as another of those conundrums, another of those histories that might have happened, should have happened, but didn't happen. 


\section{The History that Didn't Happen}

In 1796, the American Philosophical Society announced a competition and posted a substantial cash prize for the best plan for a system of education in the United States. Nothing further came of either of the winning plans or of any of the others. They all died stillborn. And so did every other Enlightened scheme for the systematic elaboration of an appropriately republican education, whether it came from the nonentities who won the APS competition or from far more famous men (Madsden, 1974, pp. 74-5).

Washington himself devoted the major portion of his first message to Congress to education. He still called his countrymen to "promote ... as an object of primary importance institutions for the general diffusion of knowledge" in his Farewell Address eight years later. But no more came of his urgings than of those which won the medal and the money of the APS (Madsden, 1974, pp. 66-7).

Jefferson, Madison, Monroe, Adams - all the early presidents - promulgated or endorsed plans for national schooling, and so did early American playwrights, poets, and intellectuals of every sort. Tom Paine considered self-government "a chimera in the absence of universal education". Benjamin Rush considered it "absolutely necessary" that the young nation be made a massive republican schoolhouse. But no more came of their cumulative authority than of Washington's (Cremin, 1980, p. 23; Madsden, 1974, pp. 67, 64; see also Karier, 1986, p. 30, Bailyn, 1960, pp. 45-6).

\section{The Limits of Enlightenment}

All these schemes and systems were conceived within the assumptions of the American Enlightenment. But that Enlightenment mattered in America only as it had ever mattered in America, as the outlook of an urban and urbane minority, in a country in which the vast majority of the people lived in the country. In 1790, the year of the first federal census, $95 \%$ of the population was rural. Forty years later, more than $90 \%$ were still rural. To the time of the Civil War, only a fifth of all Americans lived in places of 2500 or more, the Census threshold for a city (Kaestle, 1983, p. 13).

Grand projects of national education were all but irrelevant to the needs of the scattered and semi-autonomous communities of the young republic. The localism of the provincial masses stymied the nation-building endeavor of the cosmopolitan elite in everything that touched on people's intimate interests in the rearing of their young. Parochial inertia prevailed again and again over the distant imaginings of the great men, whether those great men were in Philadelphia or Washington (or, for that matter, in Paris or in flight from the authorities in Paris).

The education that those rustics prized and protected from outside interference was, by Enlightened standards, a rough and rude business. By almost all accounts - and we have hundreds of accounts - the schools of the early republic were dismal places. Almost without exception, they were drafty one-room hovels. Some had desks and chairs at which students sat and shivered. Most lacked even such minimal amenity. Most had nothing but backless benches high enough that more than a few youngsters' feet did not touch the floor. As one memoir said of such seating, "a more complete rack of torture and machine for making cripples could hardly be invented” (Kaestle, 1983, p. 16; Freeberg, 2001, p. 69).

The students themselves ranged in age from four to fourteen, all thrown promiscuously together in that one room no matter what their prior schooling or ability. Their teachers had little training and less incentive. They were poorly paid and hardly ever highly esteemed. The only pedagogy any of them practiced was rote 
memorization and recitation. Teachers never pressed students even to understand their texts, let alone to think critically or creatively about them. "Keeping silence" was, for such teachers, "the very summit of pedagogical excellence” (Kaestle, 2001, pp. 18-9; see also Pangle, 1993, pp. 104-5; Green, 2008, pp. 121-2; Freeberg, 2001, pp. 79, 85; Greer, 1972, p. 62).

But keeping silence, in classrooms pervaded by boredom and drudgery, was not easy. Pupils hated their teachers and books, and teachers responded to their hatred with force. Corporal punishment was nearly universal in the schools of the new nation. Students considered themselves "peculiarly fortunate" if they were "not whipped more than three times a week". Teachers swore that their scholars had become so accustomed to the rod that "they did not know what school [was] without it" (Freeberg, 2001, pp. 87, 109).

Every aspect of such schooling was antithetical to Rousseau's precepts. He abjured all corporal punishment, never resorted to rote, and urged that early education be conducted out-of-doors, not in crowded classrooms, by experience, not by books. Indeed, he kept Emile out of school entirely before the age of twelve, to keep him from "the crushing force of social conventions". And he kept Emile always to his own developmental stage, where early American schools jumbled scholars of all ages and stages (Rousseau, 1911, pp. 5-6).

Ironically, the Old World education that Emile challenged was, in its own way, the New World norm. American education too extinguished the curiosity and love of learning that Rousseau considered natural in children. It too turned inquisitive seekers into passive recipients of adult precepts. It too depended on fear and force and presumed innocent young people precociously corrupt and knowing.

In short, the schools proposed by the devotees of the Enlightenment were no better, by Rousseau's standards, than the ones they would have replaced. They all aimed to train habits of industry from an early age, where Rousseau cherished childish idleness and the habit of having no habits. They all thought the young in peril, where he believed them innocent. They all demanded "absolute obedience to ... authority", where he begged parents and teachers to abandon such words as "obey”, “duty”, and "obligation”. They all wanted stern moral oversight from the first, where he held that children could make no sense of moral relations before adolescence (Reinier, 1982, pp. 157-8 (quoting Benjamin Rush; Rousseau, p. 53)).

The heirs of that early national impulse to Enlightenment, who beseeched what Rousseau scorned, were the common school reformers of the antebellum era. They and their acknowledged leader, Horace Mann, set the country on a path to mandatory universal schooling on which Americans have congratulated themselves ever since.

But their achievement was every bit as antithetical to Rousseau's vision as the schemes of their predecessors and a great deal more equivocal than they proclaimed. In states such as Massachusetts, schooling was already very nearly universal when Mann became commissioner of education in the 1830s. His triumph was, more than anything else, to bring the ramshackle variety of local education under his own centralized bureaucratic sway. He succeeded, to the extent that he did, not because the Commonwealth was eager for the bureaucratic routinization he offered but because the citizenry came to fear its alternative.

By the 1830s, immigrants threatened to inundate the land. The newcomers sparked widespread worry that they would turn the nation into the "heterogeneous, incoherent, distracted mass" of which Jefferson warned. And in the large seaports, especially, that worry was compounded by increasing poverty, class polarization, and rioting (Jefferson, 1974, pp. 124-5).

Mann's common schools provided reassuring symbols of social cohesion and control: "a wise and liberal system of police, by which property and life and the peace of society" were secured. They taught "the habit of 
moving in concert with others". They trained American youth "in the social habits of regularity, punctuality, orderly concerted action, and self-restraint”. Where the Founders favored mass public education to preserve and promote republican citizenship, their inheritors embraced it to avert disorder in a splintering society (Karier, 1986, p. 51; Greer, 1972, p. 73).

Neither rationale owed anything to Rousseau, whose influence mattered in the early republic as it matters in modern-day America, only at the margins. An odd lot of visionaries have shared his outlook and even drawn deliberately on his writings. But they have all been outside the American educational mainstream, which has always been and still is oblivious to almost everything that Rousseau valued.

\section{Conclusion}

So I come to one last plaguing perplexity, one last conundrum, one last historical mis-fire. But this time I come to wonder whether these vacancies in the historical record testify not to something gone awry, something of cosmic illogic, but to something right and revealing, something with which I have not reckoned.

All the missing histories that I have conjured - all the histories that might and should have been - have been predicated on the reality of the mythic America that prizes persons, not masses, idiosyncrasy, not uniformity, and individual development, not social cohesion. In the perspective of that mythic America, Rousseau's irrelevance is mystifying.

But perhaps the irrelevance of Rousseau is illuminating rather than perplexing. Perhaps history does not deceive or make mistakes after all. Perhaps it is we who deceive ourselves and make mistakes about ourselves. Perhaps the history that happened is the history that should have happened.

Perhaps history has been trying, for two centuries and more, to tell us that we do not treasure freedom, individuality, and personal development as we say we do. Perhaps we have always preferred other gods, more conformist and collective, more controlling and coercive.

Perhaps one day we will grow up and admit as much.

\section{References}

Bailyn, B. (1960). Education in the forming of American society. Chapel Hill, NC: University of North Carolina Press.

Cremin, L. (1980). American education: The national experience, 1783-1876. New York: Harper and Row.

Freeberg, E. (2001). The education of Laura Bridgman: First Deaf and Dumb Person to learn language. Cambridge, MA: Harvard University Press.

Green, J. (2008). Military education and the emerging middle class in the Old South. Cambridge, England: Cambridge University Press.

Greer, C. (1972). The great school legend: A revisionist interpretation of American public education. New York: Viking.

Jefferson, T. (1974). Notes on the State of Virginia. New York: Viking.

Kaestle, C. (1983). Pillars of the Republic: Common schools and American society, 1780-1860. New York: Hill and Wang.

Karier, C. (1986). The individual, society, and education: A history of American educational ideas (2nd ed.). Urbana, IL: University of Illinois Press.

Madsden, D. (1974). Early national education: 1776-1830. New York: John Wiley.

Pangle, L. T. (1993). The learning of liberty: The educational ideas of the American founders. Lawrence, KA: University Press of Kansas.

Reinier, J. (1982). Rearing the Republican child: Attitudes and practices in Post-revolutionary Philadelphia. William and Mary Quarterly, 39, 150-63.

Rousseau, J. J. (1911). Emile. London: Everyman Library, Dent.

Spurlin, P. (1969). Rousseau in America, 1760-1809. University, AL: University of Alabama Press. 